\title{
Self-perception of non-cognitive skills among undergraduate health students during Covid-19
}

\section{Autopercepção de habilidades não cognitivas entre estudantes de graduação em saúde durante a Covid-19}

\author{
Gilberto da Cruz Leal'1 (1) | gilbertoleal@usp.br \\ Edson Zangiacomi Martinez' (1) edson@fmrp.usp.br \\ Patrícia Pupin Mandrá' (1) ppmandra@fmrp.usp.br \\ Tatiane Martins Jorge ${ }^{1}$ (D) tmjorge.fono@gmail.com
}

\begin{abstract}
Introduction: The social isolation in Brazil imposed in response to the COVID-19 pandemic has changed the way in which many undergraduate students have been learning, especially those involved in academic activities, as they now have remote rather than in-person classes. These changes may be beneficial if one considers this time favorable for improving non-cognitive skills, such as self-knowledge, resilience, collectivity, versatility, adaptability and leadership.
\end{abstract}

Objective:This study was aimed at investigating how undergraduate health students in Southeastern and Southern Brazil perceived improvement in non-cognitive competencies during the rapid changes imposed in response to the COVID-19 pandemic.

Method: This study evaluated 954 undergraduate health students at Brazilian higher education institutions. An online questionnaire consisting of 25 items was used to collect demographic and academic data as well as the subjects' perception of non-cognitive feelings and skills during the remote continuation of the undergraduate course. The undergraduate health students' perceptions were measured using a 10-point Likert intensity scale ranging from "very little" to "very much". This questionnaire was previously validated in a group of 20 undergraduate students attending different health courses at a higher education institution in the State of São Paulo.

Result: Correspondence analysis demonstrated that non-cognitive skills, including feelings, were perceived with varying intensities by the undergraduate students, thus making it possible to observe positive and negative impacts resulting from the changes they experienced. Students in the first and second semesters of their first year of studies tended to show lower collaboration scores than students in the third and fourth semesters; on the other hand, students in the first semester tended to show higher scores of openness to new experiences than students in the subsequent semesters.

Conclusion: Overcoming procrastination, taking the lead in their studies, collaborating with peers, and being open to the new were the noncognitive skills that were strongly perceived during the pandemic. In addition, frustration, lack of motivation, and emotional instability were strongly felt by the students, who considered that the COVID-19 pandemic had negatively affected their performance.

Keywords: Pandemics; Coronavirus Infections; Students; Aptitude.

\section{RESUMO}

Introdução: O período de isolamento social imposto no Brasil em resposta à pandemia tem alterado o modo de aprender de muitos estudantes universitários do Brasil, em especial o dos que tiveram suas atividades acadêmicas, que antes eram presenciais, transferidas para o modo remoto. Tais mudanças podem ser benéficas se considerarmos que este pode ser um momento favorável para o aprimoramento de habilidades não cognitivas, como autoconhecimento, resiliência, coletividade, versatilidade, adaptabilidade e liderança.

Objetivo: Este estudo teve como objetivo investigar como os universitários da área da saúde, das regiões Sudeste e Sul do país, têm percebido o aprimoramento de competências não cognitivas durante as rápidas mudanças impostas pela pandemia.

Método: O estudo contou com a participação de 954 estudantes da área da saúde matriculados em instituições de ensino superior brasileiras. Um questionário on-line composto por 25 questões foi utilizado para coletar dados demográficos e acadêmicos, sentimentos e habilidades não cognitivas percebidas durante a continuidade "a distância" do curso de graduação. A percepção dos universitários foi aferida a partir de escalas Likert de intensidade, de 10 pontos (de 1 a 10), variando de "muito pouco" a "muito". Previamente à aplicação desse questionário, foi feita sua validação por um grupo de juízes, composto por 20 estudantes de graduação de uma instituição de ensino superior do interior do estado de São Paulo, de diferentes cursos da saúde.

Resultado: A análise de correspondências demonstrou que as habilidades não cognitivas, bem como as sensações investigadas, foram percebidas em variadas intensidades pelos estudantes universitários, sendo possivel notar impactos positivos e negativos decorrentes das mudanças vivenciadas. Os alunos do primeiro e segundo semestres da graduação tenderam a ser menos colaborativos do que os discentes do terceiro e quarto semestres; em contrapartida, os alunos ingressantes tenderam a ser mais abertos ao novo quando comparados àqueles dos demais semestres.

Conclusão: Vencer a procrastinação, assumir o protagonismo nos estudos, colaborar com os colegas e estar aberto ao novo foram habilidades não cognitivas fortemente percebidas durante a pandemia. Além disso, frustração, falta de motivação e desestabilidade emocional foram fortemente sentidas pelos estudantes, que consideraram que a pandemia afetou negativamente os estudos.

Palavras-chave: Pandemias; Infecções por Coronavírus; Estudantes; Habilidade.

1 Universidade de São Paulo, Ribeirão Preto, São Paulo, Brazil.

\begin{tabular}{l|l} 
Chief Editor: Rosiane Viana Zuza Diniz. & Associate Editor: Antonio da Silva Menezes Junior
\end{tabular}

Received on 04/30/21; Accepted on 10/21/21. | Evaluated by double blind review process. 


\section{INTRODUCTION}

Brazil and the world countries have been faced with many changes resulting from the COVID-19 pandemic. COVID-19 is a potentially serious respiratory infection caused by the coronavirus SARS-CoV-2 ${ }^{1,2}$. Due to the high infection rate and severity of COVID-19, many governments have adopted measures to stimulate social distancing and some have even adopted lockdown policies ${ }^{1,3-7}$.

In March 2020, the Brazilian Health Ministry issued ministerial ordinance no. 454, declaring a "state of community transmission of the coronavirus" ${ }^{\prime \prime}$. Social isolation was deemed necessary in an attempt to slow the propagation of the virus and to reduce the death toll. The change in the relationship dynamics between individuals due to the COVID-19 pandemic has brought implications that go far beyond the sanitation issues ${ }^{5}$. One of the effects was the substitution of part of the in-person classes with remote ones ${ }^{3}$.

In Brazil, the Ministry of Education and Culture authorized the use of digital devices by higher education institutions by means of ministerial ordinance no. 343. Teachers and students had to adapt to this new learning modality within a few days ${ }^{9}$. The Brazilian National Health Council ${ }^{10}$ does not recommend that health courses be offered solely via distance learning ${ }^{11}$. Therefore, many practical learning activities were maintained and/or postponed, whereas theoretical classes were replaced by remote learning.

It is possible to note in previously published conversations and reports that undergraduate health students have experienced feelings of uncertainty, mainly regarding the postponement of practical classes and the replacement of learning tools ${ }^{12}$. The interruption of in-person activities also resulted in the postponement of research and extension projects, including the students' graduation, enrollment in graduate programs, and finding employment in the job market ${ }^{13}$. This change, imposed in response to the pandemic, may be beneficial if one considers this time to be favorable for the improvement of non-cognitive skills ${ }^{14,4}$, such as selfknowledge, resilience, collectivity, versatility, adaptability, and leadership ${ }^{4}$.

Non-cognitive competencies, also known as socioaffective skills, have been as valued as, or even more so, than cognitive ones in the job market ${ }^{14}$. Moreover, the window of opportunity for the development of non-cognitive skills is wider than that for cognitive ones ${ }^{15}$ and therefore should be explored.

In view of the notable changes in modes of learning and teaching resulting from the social isolation, including several feelings involved in this process, this study was designed to investigate how undergraduate health students at higher education institutions in the Southeastern and Southern Brazil have perceived their non-cognitive competencies during the rapid changes accompanying the COVID-19 pandemic.

\section{METHODS}

This study was approved by the local human research ethics committee according to protocol number CAAE 37056720.2.0000.5440 (Hospital das Clínicas da Faculdade de Medicina de Ribeirão Preto), in which all the subjects read the text and participated voluntarily in the study.

This is a cross-sectional, descriptive, quantitative study of undergraduate health students in the Southeastern (São Paulo, Rio de Janeiro, Minas Gerais, and Espírito Santo) and Southern Brazil (Paraná, Santa Catarina, and Rio Grande do Sul). It was initially aimed at students from all of the Brazilian regions, but since answers from the North, Northeast and Midwest represented only $9 \%$ of the total, we opted to focus on the aforementioned areas to avoid disagreements.

The sample comprised of 954 undergraduate students, selected without regard to gender, age, enrollment year, and course modality, who met the following inclusion criteria: belonging to the health area, being enrolled at Brazilian higher education institutions, and performing their academic activities in 2020 during the social isolation period due to the COVID-19 pandemic.

Survey data were collected between October 12, 2020 and January 18, 2021. An online questionnaire was used to reach the undergraduate students in two large regions of Brazil. The questionnaire was created using the Google Forms, a survey management application protected by virtual locks and keys to ensure data storage safety and considered satisfactory by audit reports (SSAE 16 and ISAE 3203 type II).

This online questionnaire was previously validated for its content by a group of 20 undergraduate students selected by convenience sampling, regardless of gender, age or enrollment year, who were attending different health courses at a higher education institution in the state of São Paulo and who were performing their academic activities in 2020 during the social isolation period. Questionnaire validation was performed by using Lawshe method, known as the content validity index $(\mathrm{CVI})$. Each of the questions created by the researchers was evaluated on a three-point scale as follows: "essential", "useful, but not essential", or "not necessary". The CVI for each question is given by $\mathrm{CVI}=(\mathrm{Ne}-\mathrm{N} / 2) /(\mathrm{N} / 2)$, where $\mathrm{Ne}$ is the number of undergraduate students indicating "essential" and $\mathrm{N}=20$ is the total number of students. The question was maintained in the questionnaire if it had a concordance rate of at least $78 \%$, which was considered acceptable.

After its validation, the final questionnaire consisted of 25 items, in which five were on demographic and academic data 
of the undergraduate students (i.e., age, city where the higher education institution was located, the course being attended, current year/semester, learning modality before the COVID-19 pandemic), and 20 were on the study topic (i.e., feelings and non-cognitive skills perceived during the continuation of the undergraduate course with a distance learning modality).

The link giving access to the free-consent form and the questionnaire was made available through the researchers' social networks (i.e., Instagram, WhatsApp, and Facebook), as well as by an e-mail sent to the undergraduate committees of the higher education institutions. The procedure to obtain data for the study followed the security recommendations of the Checklist for Reporting Results of Internet E-Surveys, which was used as a guideline for online data collection ${ }^{16}$. The undergraduate health students' perceptions were measured by a 10-point Likert intensity scale, ranging from "very little" to "very much". In addition, the participant could choose the option "NR" (i.e., "I don't know" or "I don't want to answer"). The variation from 1 to 10 facilitates discrimination and visualization by the respondents, thus enabling the researchers to further refine the results ${ }^{17}$.
Correspondence analysis (CA), which is an exploratory statistical technique describing associations or similarities between the categorizations of qualitative variables, was used for data analysis ${ }^{18}$. This technique is widely indicated for Likert-type scales and allows a visual analysis of the existing relationships by reducing the dimensionality of the qualitative data set into contingency tables ${ }^{19}$., The CA package of the $\mathrm{R}$ software, version 3.6.2, was used in the implementation of the $C A^{20}$.

The results of the CA are represented in a Cartesian graph, called a correspondence map, which visually shows the relationship between classes for each variable. Each axis of this diagram is referred to as a dimension, and in the present study, it describes the scores on a 10-point scale for 20 questions (labelled from Q1 to Q20) related to non-cognitive feelings and skills perceived by the respondents (Table 1). The relative proximity between the respective points in the correspondence map is related to the level of association between them. In some applications of CA to data measured on Likert scales, the configuration of the points in the plane resembled a parabola, which is referred to as a horseshoe or Guttman effect. This occurs

Table 1. Presentation of the questions asked in this study.

\begin{tabular}{|c|c|}
\hline Label & Item \\
\hline Q2 & How much did you feel like you had to adapt to the new way of learning and studying? \\
\hline Q3 & How much did you feel like you had to take the lead (autonomy) in your studies? \\
\hline Q4 & How much motivated did you feel for these changes? \\
\hline Q6 & How much did you collaborate with your peers in this process? \\
\hline Q7 & How much did you feel emotionally stable with these changes? \\
\hline Q8 & How much did you feel like you overcame challenges in this process? \\
\hline Q9 & How much did you manage to keep your focus on your studies and academic activities? \\
\hline Q13 & How much more organized do you feel you have become during your studies? \\
\hline Q14 & How much more dedicated to your studies do you feel you have become? \\
\hline Q15 & How much did you have to do to overcome procrastination during school days? \\
\hline Q16 & How much do you feel like you developed a more inquisitive mindset? \\
\hline Q17 & How much do you feel like you managed to control more your time? \\
\hline Q18 & How much did this period of social isolation positively affect your studies? \\
\hline Q19 & How much did this period of social isolation negatively affect your studies? \\
\hline
\end{tabular}


when the first dimension of the graph is very dominant and the second one is a quadratic transformation of the former ${ }^{21}$. In CA, the total data variation is called inertia, which is decomposed in each dimension of the correspondence map. The inertia related to each dimension indicates the proportion of total variability explained by the respective axis.

The options "I don't know" or"I don't want to answer" are represented in the correspondence map as a supplementary point and they are labelled as "NR" (no response). In CA, a supplementary point is an additional option that does not contribute to the inertia decomposition and consequently does not affect the position of the other points in the correspondence map.

The non-parametric Wilcoxon rank-sum test was used to compare the distribution of the students' age with scores less or equal to 5 in each question of the instrument, to the students scoring more than 5 points. The standardized Wilcoxon Rank-Sum Statistic (WRS) was used as an effect size measure interpreted as a Z-score, where absolute values higher than 1.96 corresponded to significant differences in a statistical sense $(p<0.05)$. Fisher's exact test was used to compare the frequencies of students scoring 5 or more in each question of the instrument and the learning environment (distance course, in-person, and semi-in-person classes). Kruskal-Wallis test was used to verify the association between academic semesters and the questionnaire answers.

\section{RESULTS}

Of the 954 students who participated in the study, 629 (65.9\%) were from the state of São Paulo, 63 (6.6\%) from Rio de Janeiro, 132 (13.8\%) from Minas Gerais, 1 (0.1\%) from Espírito Santo, 27 (2.8\%) from Paraná, 34 (3.6\%) from Santa Catarina, and 68 (7.2\%) from Rio Grande do Sul.

Table 2 shows the sample description according to the geographic region, age, undergraduate course, year/semester, and modality before the pandemic. The age of the participants ranged from 17 to 62 years, with a mean age of 22.5 and a median of 21 years.

Chart 1 shows the correspondence map generated by the analysis. One can observe that the configuration of the correspondence map shows a horseshoe-like pattern and the 10-point Likert intensity scale is represented from left to right when projected onto the $\mathrm{X}$-axis of the graph.

This dimension represents an inertia of $84.2 \%$, that is, a great part of the data variation can be explained by this axis. The second dimension, consequently, represents an inertia of $11.6 \%$. Therefore, both dimensions together represent $95.6 \%$ of the data variation.

CA demonstrated that behaviors such as "overcoming procrastination" (Q15), "taking the lead in the studies" (Q3), "collaborating with colleagues" (Q6) and "opening up to new experiences" (Q12) are represented on the right side of the correspondence map, suggesting that the participants had a high perception of them.

Question Q20 is represented farthest to the right in the correspondence map, suggesting that the undergraduate

Table 2. Sample characterization: students' demographic and academic data.

\begin{tabular}{|c|c|c|c|}
\hline \multicolumn{2}{|r|}{ Categories } & \multirow{2}{*}{$\frac{\mathbf{n}}{825}$} & \multirow{2}{*}{$\begin{array}{c}\% \\
86.5\end{array}$} \\
\hline Country & Southeastern & & \\
\hline region & Southern & 129 & 13.5 \\
\hline \multirow{8}{*}{ Age group } & Under 20 years old & 334 & 35.1 \\
\hline & 21 to 25 & 504 & 52.8 \\
\hline & 26 to 30 & 75 & 7.9 \\
\hline & 31 to 35 & 14 & 1.5 \\
\hline & 36 to 40 & 10 & 1.0 \\
\hline & 41 to 45 & 9 & 0.9 \\
\hline & 46 to 50 & 4 & 0.4 \\
\hline & Over 51 years old & 4 & 0.4 \\
\hline \multirow{12}{*}{ Course } & Biomedical sciences & 27 & 2.8 \\
\hline & Dentistry & 58 & 6.1 \\
\hline & Medicine & 252 & 26.4 \\
\hline & Nursing & 119 & 12.5 \\
\hline & Nutrition/metabolism & 101 & 10.6 \\
\hline & Occupational therapy & 59 & 6.2 \\
\hline & Pharmacy & 39 & 4.1 \\
\hline & Psychology & 89 & 9.3 \\
\hline & Physical education & 25 & 2.6 \\
\hline & Physiotherapy & 39 & 4.1 \\
\hline & Speech therapy & 121 & 12.7 \\
\hline & Others & 25 & 2.6 \\
\hline \multirow{7}{*}{$\begin{array}{c}\text { Year/ } \\
\text { period }\end{array}$} & $1^{\text {st }}$ Year ( $1^{\text {st }} \& 2^{\text {nd }}$ semesters $)$ & 232 & 24.3 \\
\hline & $2^{\text {nd }}$ Year ( $3^{\text {rd }} \& 4^{\text {th }}$ semesters $)$ & 224 & 23.5 \\
\hline & $3^{\text {rd }}$ Year $\left(5^{\text {th }} \& 6^{\text {th }}\right.$ semesters $)$ & 208 & 21.8 \\
\hline & $4^{\text {th }}$ Year $\left(7^{\text {th }} \& 8^{\text {th }}\right.$ semesters $)$ & 179 & 18.8 \\
\hline & $5^{\text {th }}$ Year $\left(9^{\text {th }} \& 10^{\text {th }}\right.$ semesters $)$ & 94 & 9.8 \\
\hline & $6^{\text {th }}$ Year $\left(11^{\text {th }} \& 12^{\text {th }}\right.$ semesters $)$ & 16 & 1.7 \\
\hline & $6^{\text {th }}$ Year $\&$ beyond & 1 & 0.1 \\
\hline \multirow{3}{*}{$\begin{array}{l}\text { Course } \\
\text { modality } \\
\text { before } \\
\text { pandemic }\end{array}$} & In-person & 914 & 95.8 \\
\hline & Semi-in-person & 34 & 3.6 \\
\hline & Remote (online) & 6 & 0.6 \\
\hline
\end{tabular}


Chart 1. Correspondence Map.

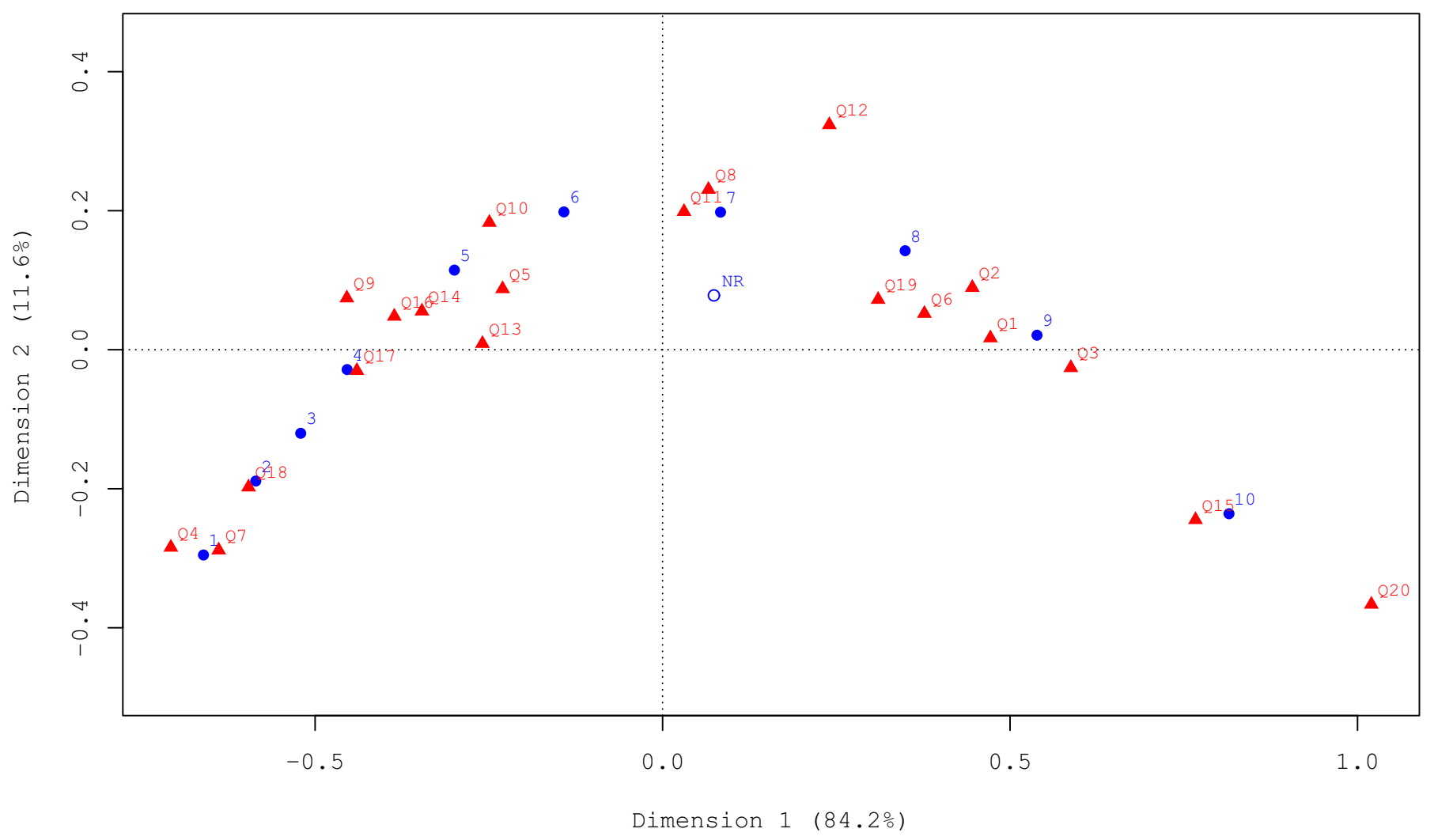

$\mathrm{Q}$ (in red): question asked in this study; Highlighted in blue: Likert scores (from 1 to 10 points).

students had a strong perception that the development/ improvement of non-cognitive skills is important for their professional success.

On the other hand, the undergraduate students reported a high degree of frustration (Q1) and low level of motivation (Q4) regarding the changes imposed during the COVID-19 pandemic. For the respondents, the changes they have been experiencing affected their academic performance (Q19), showing that their feeling of emotional stability (Q7) was little perceived, indicating that they had little control of their time (Q17).

Table 3 shows the median and the interquartile range of the age of the respondents, considering those scoring 5 points or less, and more than 5 points, in each question of the instrument. Table 3 also shows the WRS and the corresponding $\mathrm{p}$-value for the Wilcoxon test, comparing the age distribution between the groups. Although there are some absolute values of WRS greater than 1.96 and corresponding $p$-values less than 0.05 for some questions of the instrument, it can be observed that the medians and interquartile ranges are quite close when comparing between the groups. These statistical differences are probably due to the low variability of age and have little practical significance. Of the 954 students, 838 (87.9\%) were under 25 years old.

Concerning the learning environment, 914 were enrolled in in-person courses, 6 were enrolled in semi in-person courses,
Table 3. Age (median and interquartile range).

\begin{tabular}{ccccccc}
\hline \multirow{2}{*}{ Label } & \multicolumn{2}{c}{ Scores $\leq 5$} & \multicolumn{2}{c}{ Scores $>5$} & \multirow{2}{*}{ WRS } & p value \\
\cline { 2 - 5 } & Median & Q1-Q3 & Median & Q1-Q3 & & \\
\hline Q1 & 22 & $20-24$ & 21 & $20-23$ & 3.94 & $<0.01$ \\
Q2 & 21 & $20-24$ & 21 & $20-23$ & 1.61 & 0.11 \\
Q3 & 22 & $20-24$ & 21 & $20-23$ & 1.63 & 0.10 \\
Q4 & 21 & $20-23$ & 22 & $20-25$ & 4.68 & $<0.01$ \\
Q5 & 21 & $20-24$ & 21 & $20-23$ & 0.05 & 0.96 \\
Q6 & 22 & $20-24$ & 21 & $20-23$ & 3.17 & $<0.01$ \\
Q7 & 21 & $20-23$ & 22 & $20-24$ & 1.27 & 0.20 \\
Q8 & 21 & $20-23$ & 21 & $20-23$ & 0.63 & 0.53 \\
Q9 & 21 & $20-23$ & 21 & $20-24$ & 0.90 & 0.37 \\
Q10 & 21 & $20-23$ & 22 & $20-24$ & -2.51 & 0.01 \\
Q11 & 21 & $20-23$ & 21 & $20-23$ & -0.28 & 0.78 \\
Q12 & 21 & $20-23$ & 21 & $20-23$ & 0.19 & 0.85 \\
Q13 & 21 & $20-23$ & 21 & $20-23$ & 0.31 & 0.76 \\
Q14 & 21 & $20-23$ & 22 & $20-24$ & 2.32 & 0.02 \\
Q15 & 22 & $20-25$ & 21 & $20-23$ & 1.87 & 0.06 \\
Q16 & 21 & $20-23$ & 21.5 & $20-24$ & -0.26 & 0.79 \\
Q17 & 21 & $20-23$ & 21 & $20-24$ & 0.49 & 0.62 \\
Q18 & 21 & $20-23$ & 22 & $20-24$ & 2.65 & 0.01 \\
Q19 & 21 & $20-24$ & 21 & $20-23$ & 1.21 & 0.23 \\
Q20 & 21 & $20-23$ & 21 & $20-23$ & 0.02 & 0.98 \\
\hline
\end{tabular}

WRS: standardized Wilcoxon Rank-Sum statistics. 
and 34 in a remote learning environment. Table 4 shows the frequencies of students scoring more than 5 points for each question of the instrument and the learning environment (remote course, in-person, and semi in-person classes). Fisher's exact test does not show significant associations between the scores and the learning environment.

Students in the first and second semesters of their first year of studies tend to have lower scores in Q6 (mean of 6.9 and 7.0, respectively) than students in the third and fourth semesters (mean of 7.7 and 7.8, respectively, KruskalWallis test, $\mathrm{p}<0.01)$. Students in the first semester tend to have higher scores in Q12 than students in the subsequent semesters (Kruskal-Wallis test, $p<0.01$ ). The mean score in Q12 among the students in the first semester was 7.7, and among the students from the second to fifth semesters were $7.1,7.0,6.8$, and 6.9, respectively. We found no evidence of an association between the course semester and the other items in the questionnaire.

\section{DISCUSSION}

The COVID-19 pandemic brought significant changes to the learning process of most undergraduate health students, either due to the interruption of in-person academic activities or the adoption of new methods and strategies of teaching, learning, and evaluation. These changes have led to a variety of feelings and attitudes in this population.

With regard to the positive impacts perceived by the undergraduate students, they reported increased self-direction in their studies, more effort to overcome procrastination, more collaboration with colleagues and more openness to new experiences.

It is known that procrastination is a complex phenomenon, which is very prevalent in university settings ${ }^{22}$. In the context of pandemic restrictions, particularly during changes in the learning and teaching process, the undergraduate student had to overcome procrastination, which was a very positive aspect.

Knowing how to manage and organize activities within the available time is fundamental for academic success ${ }^{23}$. This ability to manage time and meet deadlines is directly influenced by social, cultural, organizational, situational, and contextual factors $^{24}$. For an individual to achieve good time management, some competencies are important and need to be developed or improved, such as defining goals, establishing plans, creating activity lists, managing unforeseen events, and meeting deadlines ${ }^{25}$. It is possible to note that the maintenance of some academic activities during the COVID-19 pandemic may have prepared students for this time of crisis ${ }^{26}$ by developing or improving skills, such as time management.
Table 4. Percentage of participants with scores $>5$.

\begin{tabular}{ccccc}
\hline \multicolumn{5}{c}{ Learning environment } \\
\hline Label & Remote & In-person & Semi-in-person & p value \\
\hline Q1 & $28(82.4 \%)$ & $717(78.4 \%)$ & $3(50 \%)$ & 0.19 \\
Q2 & $28(82.4 \%)$ & $722(79.1 \%)$ & $2(33.3 \%)$ & 0.04 \\
Q3 & $30(88.2 \%)$ & $726(80.6 \%)$ & $6(100 \%)$ & 0.35 \\
Q4 & $10(29.4 \%)$ & $223(24.5 \%)$ & $3(50 \%)$ & 0.21 \\
Q5 & $13(41.9 \%)$ & $448(49.5 \%)$ & $1(16.7 \%)$ & 0.21 \\
Q6 & $26(81.2 \%)$ & $666(74.4 \%)$ & $4(66.7 \%)$ & 0.61 \\
Q7 & $7(20.6 \%)$ & $253(27.7 \%)$ & $4(66.7 \%)$ & 0.08 \\
Q8 & $22(64.7 \%)$ & $599(65.8 \%)$ & $4(66.7 \%)$ & 0.95 \\
Q9 & $10(29.4 \%)$ & $373(40.8 \%)$ & $4(66.7 \%)$ & 0.19 \\
Q10 & $16(48.5 \%)$ & $455(51.2 \%)$ & $4(66.7 \%)$ & 0.77 \\
Q11 & $21(61.8 \%)$ & $582(64 \%)$ & $6(100 \%)$ & 0.19 \\
Q12 & $26(76.5 \%)$ & $665(73.6 \%)$ & $6(100 \%)$ & 0.45 \\
Q13 & $13(39.4 \%)$ & $464(51 \%)$ & $4(66.7 \%)$ & 0.37 \\
Q14 & $10(29.4 \%)$ & $425(46.7 \%)$ & $4(66.7 \%)$ & 0.08 \\
Q15 & $28(84.8 \%)$ & $776(85.1 \%)$ & $2(33.3 \%)$ & 0.01 \\
Q16 & $13(39.4 \%)$ & $385(44.9 \%)$ & $2(33.3 \%)$ & 0.73 \\
Q17 & $9(26.5 \%)$ & $381(42 \%)$ & $4(66.7 \%)$ & 0.08 \\
Q18 & $9(26.5 \%)$ & $286(31.5 \%)$ & $4(66.7 \%)$ & 0.16 \\
Q19 & $26(76.5 \%)$ & $654(72.1 \%)$ & $3(50 \%)$ & 0.46 \\
Q20 & $32(94.1 \%)$ & $835(94 \%)$ & $5(83.3 \%)$ & 0.41 \\
\hline
\end{tabular}

Fisher's exact test.

Collaboration with peers is an essential element of teamwork that reveals a willingness to help colleagues both with difficulties and in the performance of procedures ${ }^{27}$. An interesting finding of the study was that freshman undergraduate students tended to be less collaborative with peers. A possible explanation for this is that teamwork is related to establishing bonds, which, in turn, implies construction and sharing time ${ }^{27}$.

During the pandemic, there was little consolidation of bonds with colleagues and the academic environment ${ }^{28}$. It was also possible to notice that students in their first academic semester tended to be more open to new perspectives when compared to students who were already enrolled. This finding corroborates that of other studies that have pointed out ${ }^{14} \mathrm{a}$ possible lack of flexibility and openness to change among students already enrolled in the course.

On the other hand, the changes experienced by the undergraduate students have also negatively affected their academic performance. Feelings such as frustration and low motivation were strongly perceived by the respondents. Frustration and distress are expected during periods of isolation, like those experienced during quarantine, as a result of some stressors such as containment, absence of physical freedom, and reduced frequency of social interactions ${ }^{29}$, identified not only among students, but in the general population ${ }^{30}$. In 
the Brazilian context, the impacts seem more evident due to the political-institutional crisis and divergences in official governmental orientations, which can amplify insecurity and anxiety ${ }^{31}$. These effects can directly interfere with the students' performance. Particularly among students, other elements, such as displacement to remote environments, may have contributed to the frustration. The sudden change from inperson to remote classes $^{30}$, technical connectivity problems, such as loss of audio and video signal ${ }^{32,14}$, and cultural issues related to the perception of remote learning as a fragile modality for the teaching-learning process ${ }^{30}$, are factors that impacted the lives of university students.

Low emotional stability was also strongly perceived by the undergraduate students. This emotional instability may be associated with high levels of stress, anxiety, depressive symptoms ${ }^{33-36}$ and suicidal thoughts ${ }^{34}$. Indeed, these feelings result from several factors, such as fear and concern with one's own and one's family health, increase in the activities and concern with academic performance ${ }^{33,34,37}$, decrease in social interactions, difficulty concentrating, and sleeping problems ${ }^{33}$.

The undergraduate students reported low motivation to change their way of learning and teaching. Nevertheless, for $\mathrm{Greco}^{37}$, the undergraduate students' motivation to keep studying was not strongly affected by the pandemic and their attitude remained similar to that in the previous period.

Based on the knowledge on the negative impact of the COVID-19 pandemic, it is very important to reflect on the establishment of academic strategies to help undergraduate students cope with these challenges and maintain their mental health. The literature ${ }^{13}$ has already shown some proposals and applications, such as adapting to online activities according to the students' agenda, developing tutoring services to help establish a healthy routine, following up and supporting the student, both individually and in small groups, and creating virtual meetings to promote integrative and/or complementary practices (aimed at minimizing stress and promoting relaxation).

Although the present study was conducted during the COVID-19 pandemic, its results can contribute to coping with future situations, especially those requiring some type of social distancing and/or interruption of in-person academic activities.

Despite the relevance of this study, the resulting data are on undergraduate students in Southeastern and Southern Brazil and therefore should not be generalized across the country or for all populations. It is also highlighted that this study investigated the improvement and/or development of non-cognitive skills through students' self-perception and not through objective measures. It is suggested that future studies use objective measures of these skills.

\section{CONCLUSION}

The rapid changes imposed in response to the COVID-19 pandemic have brought several challenges to undergraduate health students. They strongly perceived the development or improvement of non-cognitive skills, such as overcoming procrastination, taking the lead in their studies, collaborating with colleagues, and opening up to new experiences. In addition, the undergraduate students strongly perceived frustration, lack of motivation, and emotional instability, and they considered that the pandemic negatively affected their academic performance.

In this study, the undergraduate students also reported that it is important to develop and/or improve non-cognitive skills for a successful professional future.

\section{AUTHORS' CONTRIBUTION}

Gilberto da Cruz Leal and Tatiane Martins Jorge: contributed to the conception and design of the study, analysis and interpretation of the data, writing of the manuscript and relevant critical review of the intellectual content. Edson Zangiacomi Martinez and Patrícia Pupin Mandrá: contributed to the design of the study, analysis and interpretation of the data, writing of the manuscript and relevant critical review of the intellectual content.

\section{CONFLICTS OF INTEREST}

The authors declare no conflicts of interest.

\section{SOURCES OF FUNDING}

The authors declare no sources of funding.

\section{REFERENCES}

1. Omar Z, Sara B, Mostafa R. The Impact of Staying at Home on Controlling the Spread of COVID -19: Strategy of Control. Rev Mex Ing Biomed. 2021;42(1):e1051.

2. Silva GCA, Abe DK, Pedrenho NR, Vilares RN, Cordeiro MD, Coelho RF, et al. Evaluation of uro-oncological surgical treatment during the Sars-CoV-2 pandemic in a Brazilian tertiary oncology institution, the new world epicenter. Int Braz J Urol. 2021;47(2):378-85.

3. Camacho ACLF, Joaquim FL, Menezes HF, Sant'Anna RM. Tutoring in distance education in times of COVID-19: relevant guidelines. Res Soc Dev. 2020;9(5):e30953151.

4. Liang ZC, Ooi SBS, Wang W. Pandemics and Their Impact on Medical Training: Lessons From Singapore. Acad Med. 2020 Apr 17. [Epub ahead of print]

5. Sarti TD, Lazarini WS, Fontenelle LF, Almeida APSC. What is the role of Primary Health Care in COVID-19 pandemic? Epidemiol Serv Saúde 2020;29(2):e2020166

6. Kraemer MUG, Yang CH, Gutierrez B, Wu CH, Klein B, Pigott DM, et al. The effect of human mobility and control measures on the COVID-19 epidemic in China. Science 2020;1(1):1-10.

7. Parmet WE, Sinha MS. Covid-19 - the law and limits of quarantine. N Engl J Med. 2020;382(15):e28. 
8. Brasil. Ministério da Saúde. Portaria No 454, de 20 de março de 2020. Declara, em todo o território nacional, o estado de transmissão comunitária do coronavírus (covid-19). Diário Oficial da União. Brasília 2020.

9. Daniel SJ. Education and the COVID-19 pandemic. Prospects. 2020;20:1-6.

10. Brasil. Conselho Nacional de Saúde. Recomendação n॰ 048 , de 01 de julho de 2020. [access in $2021 \mathrm{Fev} 20$ ]. Available from: http://conselho.saude. gov.br/recomendacoes-cns/1250-recomendacao-n-048-de-01-de-julhode-2020.

11. Pereira RMS, Selvati FS, Ramos KS, Teixeira LGF, Conceição MV. Experience of university students in Covid-19 pandemic times. Revista Práxis. 2020;12(1 Supl):47-56.

12. Theoret C, Ming X. Our Education, Our Concerns: Medical Student Education Impact due to COVID-19. Med Educ. 2021;00:1-2.

13. Teixeira MR, Dahl CM. Recriando cotidianos possíveis: construção de estratégias de apoio entre docentes e estudantes de graduação em Terapia Ocupacional em tempos de pandemia. Rev Interinst Bras Ter Ocup. 2020;4(3):509-18.

14. Costa MLD, Paul B. Ensino remoto para estudantes de Psicologia: relato de experiência durante a pandemia. Cad Psic. 2020;1(1):1-10.

15. Berlingeri MM. Competências socioemocionais e mercado de trabalho: um estudo para o caso brasileiro [dissertation]. Ribeirão Preto: Universidade de São Paulo, Faculdade de Economia, Administração e Contabilidade de Ribeirão Preto; 2018.

16. Eysenbach G. Improving the quality of Web surveys: the Checklist for Reporting Results of Internet E-Surveys (CHERRIES). J Med Internet Res. 2004;6(3):e34.

17. Malhotra N. Pesquisa de Marketing: uma orientação aplicada. 3 ed. Porto Alegre: Bookman, 2001.

18. Kokol $P$, Vošner HB, Železnik D. Visualising nursing data using correspondence analysis. Nurse Res. 2016;24(1):38-40.

19. Greenacre MJ. Theory and applications of correspondence analysis. London: Academic Press; 1984.

20. Nenadic $\mathrm{O}$, Greenacre $\mathrm{M}$. Correspondence analysis in $\mathrm{R}$, with two-and three-dimensional graphics: the ca package. J Stat Softw 2007;20(3):1-13.

21. Clausen SE. Applied correspondence analysis: An introduction. (Vol. 121). Sage. 1998.

22. Hen $M$, Goroshit $M$. Prevention and intervention for academic procrastination in academic communities. J Prev Interv Community 2018;46(2):113-6.

23. MacCann C, Fogarty G, Roberts RD. Strategies for success in vocational education: Time management is more important for part-time than fulltime students. Learn Individ Differ. 2012;22(2):618-23.
24. Svartdal F, Dahl TI, Gamst-Klaussen T, Koppenborg M, Klingsieck KB. How Study Environments Foster Academic Procrastination: Overview and Recommendations. Frontiers in Psychology. 2020;11:540910.

25. Oliveira CT, Carlotto RC, Teixeira MAP, Dias ACG. Oficinas de gestão do tempo com estudantes universitários. Psicol Ciênc Prof. 2016;36(1):224-33.

26. O'Byrne L, Gavin B, McNicholas F. Medical students and COVID-19: the need for pandemic preparedness. J Med Ethics. 2020;46:623-6.

27. Souza GC, Peduzzi M, Silva JAM, Carvalho BG. Teamwork in nursing: restricted to nursing professionals or an interprofessional collaboration. Rev Esc Enferm USP. 2016;50(4):640-7.

28. Serra ST, Bteshe $M$, Bedirian $R$, Belz DS, Franco CF, Oliveira LSS Implementation of online mentoring at a medical school during the Covid-19 pandemic. Rev Bras Educ Med. 2021;45(sup.1):e127.

29. Brooks SK, Webster RK, Smith LE, Woodland L, Wesselym S, Greenberg N, et al. The psychological impact of quarantine and how to reduce it: rapid review of the evidence. Lancet. 2020;395:912-20.

30. Bezerra IMP. Estado da arte sobre o ensino de enfermagem e os desafios do uso de tecnologias remotas em época de pandemia do corona vírus. J Hum Growth Dev. 2020;30(1):141-7.

31. Nabuco G, Oliveira MHPP, Afonso MPD. O impacto da pandemia pela COVID-19 na saúde mental: qual é o papel da atenção primária à saúde? Rev Bras Med Fam Comunidade. 2020;15(42):253.

32. Silva FTM, Kubrusly M, Peixoto-Junior AA, Vieira LXSS, Augusto KL. Adaptations and repercussions in the experiences in a hybrid education university during the Sars-CoV-2 pandemic. Rev Bras Educ Med. 2021;45(2):e068.

33. Son C, Hegde S, Smith A, Wang X, Sasangohar F. Effects of COVID-19 on College Students' Mental Health in the United States: Interview Survey Study. J Med Internet Res. 2020;22(9):e21279.

34. Wang C, Pan R, Wan X, Tan Y, Xu L, Ho C. Immediate psychological responses and associated factors during the initial stage of the 2019 Coronavirus Disease (COVID-19) epidemic among the general population in China. Int J Environ Res Public Health. 2020;17(5):1729.

35. Volken T, Zysset A, Amendola S, Swormink AK, Huber M, Von WA, et al. Depressive Symptoms in Swiss University Students during the COVID-19 Pandemic and Their Correlate. Int J Environ Res Public Health. 2021;18:1458.

36. Chaudhary AP, Sonar NS, Banerjee M, Jamuna TR, Yadav S. Impact on Mental Health of students due to restriction caused by COVID-19 pandemic: Crosssectional study. MedRxiv preprint doi: 10.1101/2021.02.07.21250695.

37. Greco M, Maietti E, Rallo F, Reno C, Trere D, Savoia E, et al. Assessing knowledge, concerns, and risk perceptions among Italian medical students during 3 the SARS-CoV-2 pandemic. MedRxiv preprint doi: 10.1101/2021.02.04.21250922. 